\title{
Adsorption of Petroleum Fractions on Organo-Modified Calcium Bentonite
}

\author{
${ }^{1}$ Oraegbunam Charles ${ }^{*}{ }^{2}$ Ngobiri Nnaemeka \\ Department of Pure and Industrial Chemistry Faculty of Science, \\ University of Port Harcourt, Nigeria
}

\begin{abstract}
This work aims to obtain an organoclay from a local Nigerian bentonite with Cetyl trimetyl-Ammonium bromide (CTAB), a quaternary ammonium compound which possesses surfactant properties. The studied natural bentonite (calcium bentonite) was obtained from Anambra state and modified with CTAB via impregnation techniques. Modification was achieved by varying the concentration of the modifier from $0.02-0.15 \mathrm{~mol} / \mathrm{L}$. Adsorption test was carried out using Water, Petrol (PMS), Kerosene (DPK) and Automotive Gas Oil (AGO) on both modified and unmodified bentonite. The result showed that unmodified bentonite adsorbed more water than hydrocarbons while Modified bentonite adsorbed more hydrocarbons than water. The result also shows that the amount of each hydrocarbon adsorbed increases with an increase in the concentration of the modifier with a subsequent decrease in the amount of water adsorbed. This indicates that the modified bentonite was now organophilic. Therefore, this research shows that the bentonite modified with CTAB can be used in oil spill remediation and also to mop up hydrocarbons from the Environment.
\end{abstract}

Keywords: CTAB, Bentonite, Adsorption, Organophilization, Environment.

\section{Introduction}

Crude oil is an unrefined product from petroleum that consists of deposits of organic matter and hydrocarbons. Usual petroleum products such as diesel, kerosene and petrochemicals are obtained from crude oil refining. Crude oil is non-renewable and known as fossil fuel, which means that it can't be naturally replaced at consumption rate. Nigeria has crude oil as one of the most vital natural resource.

Refined products from crude oil are useful in heat generation, fueling vehicles, driving machinery and airplanes. Petrochemicals derived from crude are also used in the manufacture of chemical products such medicines, detergents and paints. However, environmental pollution through hydrocarbon contamination is a very serious problem and very critical because of the toxicity to man and the environment. Crude oil spills from operational activities is a contributory factor to environmental pollution (ABHA, SINGH, 2012). The release of hydrocarbons accidentally to the environment is known global challenge (ORJI, IBIENE, OKERENTUGBA, 2013). Body organs such as the kidney, liver and lungs can be affected through the toxicity from hydrocarbon ingestion. Also, high concentration of water contaminated by hydrocarbons is reported to be mutagenic and carcinogenic (MBHELE, 2007). The natural equilibrum interruptions between the natural environment and living species are caused by some hydrocarbon pollutants resident in water bodies (ABIOYE, 2011). To avoid this disruption, there is an urgent need for waste water treatment before releasing into water bodies and oil spill remediation.

Absorbent clay, also called bentonite has montmorillonite as its main constituent. Montmorillonite possess various properties such as swelling, catalytic, surface acidity, surface area and particle size (WANG, 2006). Bentonite is formed through the weathering of volcanic ash in an aqueous condition. Bentonite is an impure chemical form of aluminiumphyllosilicate. The two types of bentonite clay are Calcium and Sodium bentonite, Calcium bentonite is termed "Non-swelling" while sodium bentonite is termed "Swelling". People with sensitive palates can be aided by glazing their food with bentonite (ASAD, SHANTANU, AHMEDUZZAMAN, HASSAN, 2013).Clay minerals like bentonite play a crucial role in the oil industry (EMAM, 2013). Bentonite can act as an adsorbent and binder (EMAM, 2013). It can be used in adsorbing 
metallic pollutants to prevent them from groundwater contamination; also used as a drilling mud and in the production of ceramic structures, adhesives and cosmetics.

Organophilization of clay mineral is defined as the conversion of the natural clay from hydrophilic to hydrophobic using a surfactant for a specific application (SAFAEI, AGHAHOZORG, SHARIAT, PANAHI, 2008) Surfactants undergo substitution into the clay to achieve organophilization. Surfactants are represented by $\left[\left(\mathrm{CH}_{3}\right)_{3} \mathrm{NR}\right]^{+}$, where R- long chain hydrocarbon.

This work is aimed at obtaining modified clay by impregnation method. Their adsorption capacities on different concentrations of Water and Petroleum fractions (kerosene, diesel and gasoline) were examined and reported. This modified clay may use for remediation of the environment.

\section{Materials and Methods}

\section{Methodology:}

I. The modifier used was Cetyltrimetyl ammonium bromide (CTAB). The bentonite used in this experiment was obtained from Anambra State.

II. The weight of bentonite used in the experiment was kept constant at $25 \mathrm{~g}$ while the concentration of the modifier was varied.

III. The concentration of CTAB used was also varied between $0.02 \mathrm{~mol} / \mathrm{L}$ to $0.15 \mathrm{~mol} / \mathrm{L}(0.02,0.05$, $0.07,0.10$ and $0.15 \mathrm{~mol} / \mathrm{L})$.

\section{Procedure:}

i. $25 \mathrm{~g}$ of bentonite was weighed into a $250 \mathrm{ml}$ beaker.

ii. $\quad 0.729 \mathrm{~g}$ of CTAB was measured and dissolved in $100 \mathrm{ml}(0.1 \mathrm{~L})$ of distilled water.

iii. This solution of QAC (CTAB) was slowly added to the bentonite after which it was placed on a magnetic stirrer hot plate at a temperature of $80^{\circ} \mathrm{C}$ with stirring until point of incipient wetness where a paste was obtained.

iv. The beaker was then put into the oven and dried at $105^{\circ} \mathrm{C}$.

v. The modified clay was ground to fine powder, then labeled.

vi. This procedure was repeated for unmodified bentonite and different concentrations of modifier $(0.05,0.07,0.10$ and $0.15 \mathrm{~mol} / \mathrm{L})$.

\section{Adsorption Test:}

Solvents (PMS, Diesel, Kerosene and Water) were adsorbed separately on both modified and unmodified bentonite.

$-0.5 \mathrm{~g}$ of the organoclay was weighed into an empty mesh bucket .The weight of the empty mesh bucket and organoclay was recorded. The Mesh bucket containing the sample was immersed into $150 \mathrm{ml}$ of different Solvents (PMS, AGO, DPK and WATER) respectively for 30mins using a stopwatch.

-After 30mins, the bucket was removed from the solvent and allowed to drain for 10 secs. The weight of the mesh bucket was taken before and after and subtracted to determine the weight of Solvent adsorbed. $0.5 \mathrm{~g}$ of each of the different concentrations of modified bentonite was repeated with same procedure.

-The same process was repeated using PMS, Diesel and Kerosene. The adsorption of PMS, diesel and kerosene was studied according to ASTM (1998).

-The weight of Solvent Adsorbed was determined by:

(Weight of solvent + Clay + Mesh Bucket $)-($ Weight of Clay + Mesh Bucket $)$

\section{Results and Discussions}

\section{Adsorption Capacity}

The capacity of adsorption of petrochemical wastes (BTEX) and petroleum products (kerosene, diesel oil and gasoline) were studied using a quaternary ammonium compound called DTAB (Dodecyltrimethylammonium bromide) on modified and natural clay. Chikwe et al. (2018) clearly reported that the organo-clay adsorbed more organic solvents than the unmodified natural bentonite. It was also 
observed that the adsorption capacity and hydrocarbon percentage removal were directly proportional to the time of contact between the modifier (DTAB) and the adsorbents.

The Bar charts below indicate the adsorption capacities on different concentrations of the Modified and Unmodified Clay. The adsorption capacity of the clay was determined using ASTM (1998). The Modified Clay adsorbed more of diesel than other solvents. (Figures 2) However, after the process of organophilization, the modified clay showed the lowest adsorption with Water.

From the results, the modified clay adsorbed petroleum fractions (kerosene, gasoline and diesel) more efficiently than the unmodified clay.

The "Standard Methods of Testing Sorbent Performance of Adsorbents" ASTM (1982) was used in the Adsorption study of organic compounds.

The order of adsorption capacity in the Modified clay was:

Diesel > Gasoline> kerosene> Water. (Figure 2)

From the above order, it can be suggested that modified clay have better Adsorption Capacity in organic solvents when compared with Unmodified Clay.

The order of Adsorption Capacity in the Unmodified clay was:

Water> Gasoline> Diesel> Kerosene. (figure 1).

The above order suggests that unmodified clay adsorbs water more efficiently than organic solvents.

The concentration of the Cetyl-trimethyl ammonium compound (modifier) was varied and the effect of concentration on adsorption was monitored and the results were reported in figures 1, 2, 3 and tables 1, 2, 3, 4 , 5. However, It was observed that with an increase in the Concentration of the CTAB (modifier), there was an increase in the Adsorption of PMS, AGO and DPK and a decrease in the Adsorption of water.

Table 1: Diesel concentration in the modified clay

\begin{tabular}{|l|l|l|l|l|l|c|}
\hline S/N & $\begin{array}{l}\text { Conc. } \\
\text { Mol/L) }\end{array}$ & $\begin{array}{l}\text { Weight Of } \\
\text { Mesh } \\
\text { Bucket(G) }\end{array}$ & $\begin{array}{l}\text { Weight Of } \\
\text { Sample (G) }\end{array}$ & $\begin{array}{l}\text { Weight Of } \\
\text { Mesh Bucket+ } \\
\text { Sample (G) }\end{array}$ & $\begin{array}{l}\text { Weight Of Mesh } \\
\text { Bucket+ Sample+ } \\
\text { Solvent (G) }\end{array}$ & $\begin{array}{l}\text { Amount Of Solvent } \\
\text { Adsorbed (G) }\end{array}$ \\
\hline 1 & 0.02 & 5.88 & 0.50 & 6.38 & 6.54 & 0.16 \\
\hline 2 & 0.05 & 5.88 & 0.50 & 6.38 & 6.53 & 0.14 \\
\hline 3 & 0.07 & 5.88 & 0.50 & 6.38 & 6.53 & 0.15 \\
\hline 4 & 0.10 & 5.88 & 0.50 & 6.38 & 6.51 & 0.13 \\
\hline 5 & 0.15 & 5.88 & 0.50 & 6.38 & 6.50 & 0.12 \\
\hline
\end{tabular}

Table 2: Gasoline concentration in the modified clay

\begin{tabular}{|l|l|l|c|l|l|l|}
\hline S/N & $\begin{array}{l}\text { Conc } \\
\text { (Mol/L) }\end{array}$ & $\begin{array}{l}\text { Weight Of } \\
\text { Mesh } \\
\text { Bucket (G) }\end{array}$ & $\begin{array}{l}\text { Weight Of } \\
\text { Sample(G) }\end{array}$ & $\begin{array}{l}\text { Weight Of } \\
\text { Mesh } \\
\text { Bucket+ } \\
\text { Sample (G) }\end{array}$ & $\begin{array}{l}\text { Weight Of Mesh } \\
\text { Bucket+Sample } \\
\text { +Solvent(G) }\end{array}$ & $\begin{array}{l}\text { Amount Of } \\
\text { Solvent } \\
\text { Adsorbed (G) }\end{array}$ \\
\hline 1 & 0.02 & 6.39 & 0.50 & 6.89 & 7.16 & 0.27 \\
\hline 2 & 0.05 & 6.39 & 0.50 & 6.89 & 7.15 & 0.26 \\
\hline 3 & 0.07 & 6.39 & 0.50 & 6.89 & 7.14 & 0.25 \\
\hline 4 & 0.10 & 6.39 & 0.50 & 6.89 & 7.14 & 0.25 \\
\hline 5 & 0.15 & 6.39 & 0.50 & 6.89 & 7.15 & 0.26 \\
\hline
\end{tabular}


Table 3: Kerosene concentration in the modified clay

\begin{tabular}{|l|c|l|l|c|l|l|}
\hline S/N & $\begin{array}{l}\text { Conc. } \\
\text { (Mol/L) }\end{array}$ & $\begin{array}{l}\text { Weight Of } \\
\text { Mesh } \\
\text { Bucket (G) }\end{array}$ & $\begin{array}{l}\text { Weight Of } \\
\text { Sample (G) }\end{array}$ & $\begin{array}{l}\text { Weight Of } \\
\text { Mesh Bucket } \\
\text { +Sample (G) }\end{array}$ & $\begin{array}{l}\text { Weight Of } \\
\text { Mesh } \\
\text { Bucket+ } \\
\text { Sample+ } \\
\text { Solvent (G) }\end{array}$ & $\begin{array}{l}\text { Amount Of } \\
\text { Solvent } \\
\text { Adsorbed (G) }\end{array}$ \\
\hline 1 & 0.02 & 5.66 & 0.50 & 6.16 & 6.36 & 0.20 \\
\hline 2 & 0.05 & 5.66 & 0.50 & 6.16 & 6.32 & 0.16 \\
\hline 3 & 0.07 & 5.66 & 0.50 & 6.16 & 6.31 & 0.15 \\
\hline 4 & 0.10 & 5.66 & 0.50 & 6.16 & 6.29 & 0.13 \\
\hline 5 & 0.15 & 5.66 & 0.50 & 6.16 & 6.48 & 0.11 \\
\hline
\end{tabular}

Table 4: Water concentration in the modified clay

\begin{tabular}{|l|l|l|l|l|l|c|}
\hline S/N & $\begin{array}{l}\text { Conc. } \\
\text { (Mol } \\
\text { /L) }\end{array}$ & $\begin{array}{l}\text { Weight Of } \\
\text { Mesh } \\
\text { Bucket(G) }\end{array}$ & $\begin{array}{l}\text { Weight Of } \\
\text { Sample(G) }\end{array}$ & $\begin{array}{l}\text { Weight Of } \\
\text { Sample+Bu } \\
\text { cket (G) }\end{array}$ & $\begin{array}{l}\text { Weight Of } \\
\text { Sample+Buck } \\
\text { et+Solvent } \\
\text { (G) }\end{array}$ & $\begin{array}{l}\text { Amount Of } \\
\text { Solvent } \\
\text { Adsorbed (G) }\end{array}$ \\
\hline 1 & 0.02 & 6.39 & 0.50 & 6.89 & 7.00 & 0.11 \\
\hline 2 & 0.05 & 6.39 & 0.50 & 6.89 & 6.97 & 0.08 \\
\hline 3 & 0.07 & 6.39 & 0.50 & 6.89 & 6.94 & 0.05 \\
\hline 4 & 0.10 & 6.39 & 0.50 & 6.89 & 6.93 & 0.04 \\
\hline 5 & 0.15 & 6.39 & 0.50 & 6.89 & 6.91 & 0.02 \\
\hline
\end{tabular}

Table 5: Amount of solvents adsorbed by unmodified bentonite (control)

\begin{tabular}{|l|c|c|c|}
\hline Solvents & Weight Before(G) & Weight After(G) & Amount Adsorbed(G) \\
\hline Diesel & 6.89 & 6.93 & 0.04 \\
\hline Gasoline & 6.38 & 6.43 & 0.05 \\
\hline Kerosene & 6.16 & 6.19 & 0.03 \\
\hline Water $\left(\mathrm{H}_{2} \mathrm{O}\right)$ & 6.89 & 8.15 & 1.26 \\
\hline
\end{tabular}

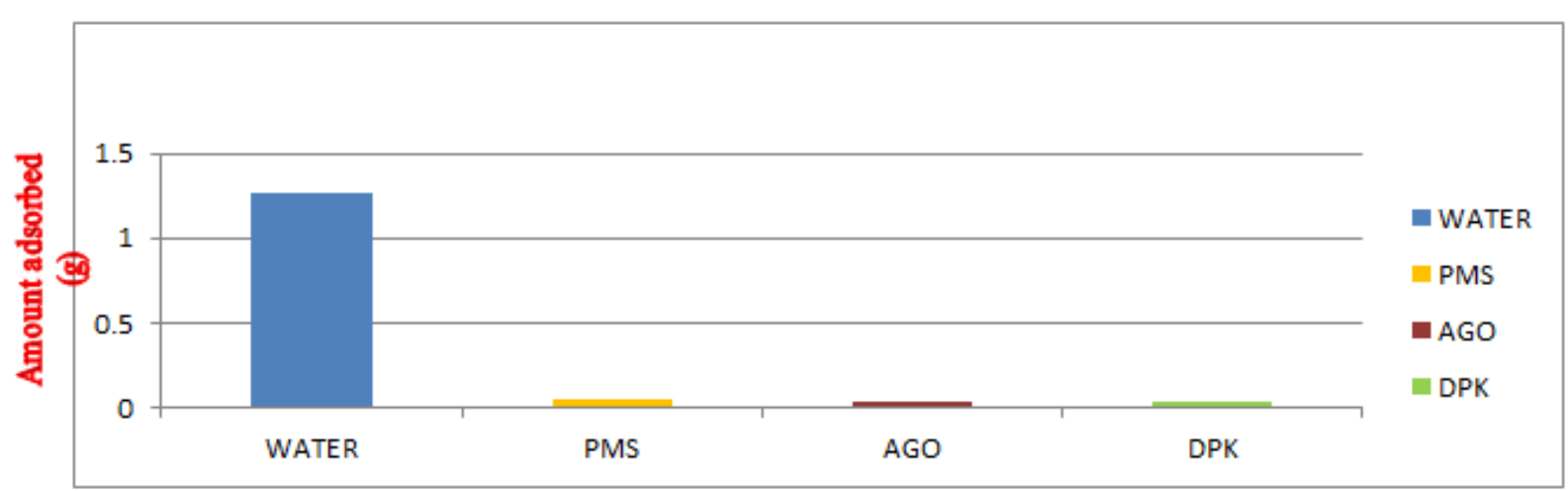

Solvent

Figure 1: Adsorption of Water, PMS, AGO and DPK on unmodified bentonite. 


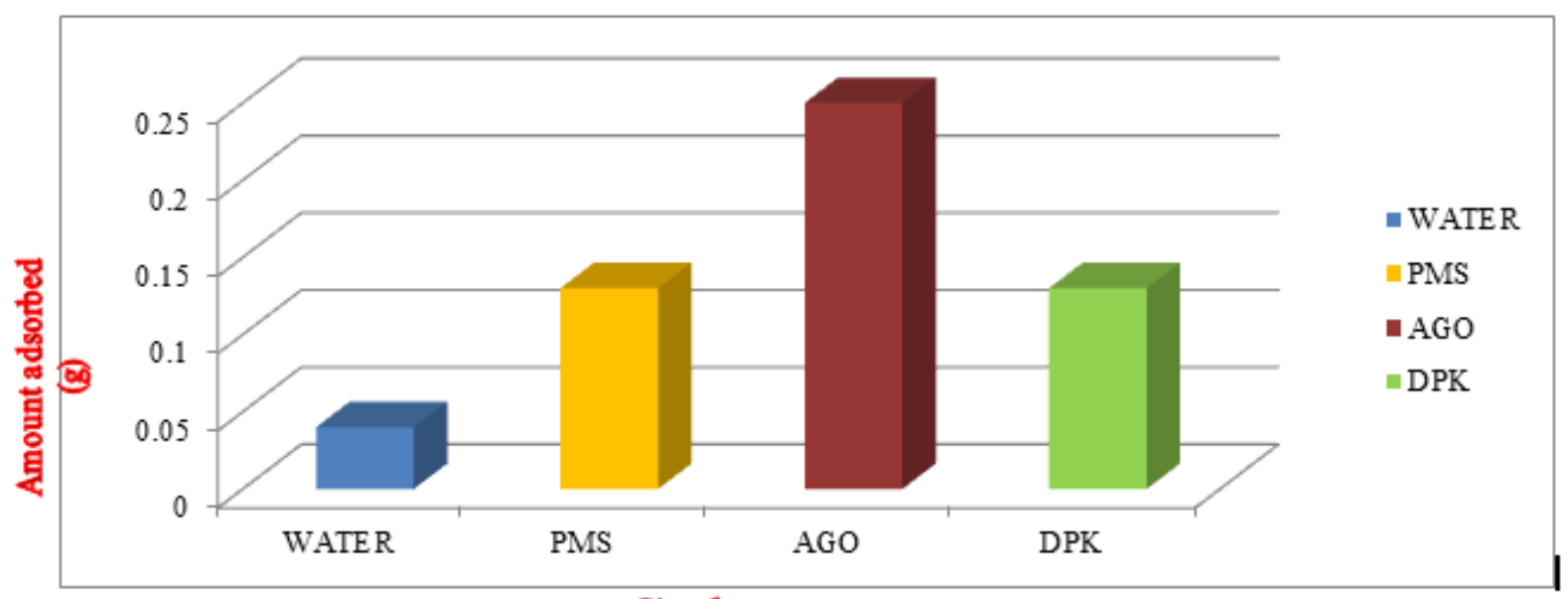

Solvent

Figure 2: Adsorption of Water, PMS, AGO and DPK on modified bentonite using 0.1M CTAB.

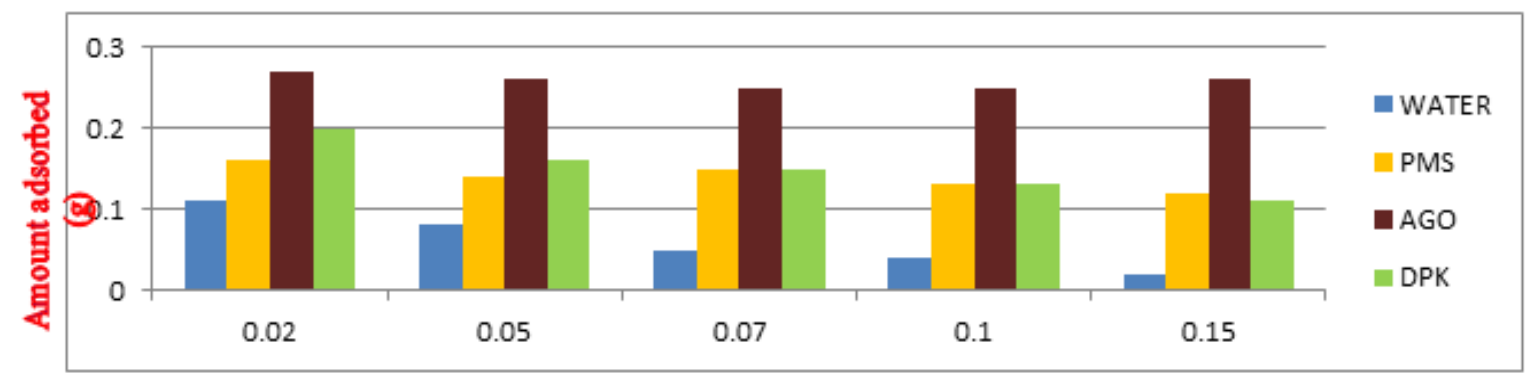

Concentration of modifier

$(\mathrm{Mol} / \mathrm{L})$

\section{Figure 3: Adsorption of Water, PMS, AGO and DPK on bentonite modified with different concentration of CTAB.}

\section{Conclusion}

The Adsorption properties of Bentonite modified with Cetyl trimetyl Ammonium Bromide (CTAB) was investigated in this study. Modification of the Clay was achieved using impregnation techniques. At the end of this study, the modified bentonite was shown to adsorb PMS, DPK and AGO. The modified bentonite showed greater Affinity for Organic Solvents compared to the Unmodified.

The unmodified showed high affinity for Water compared to the Modified Clay.

This Study demonstrates that natural clay treated with CTAB has more efficient Adsorption Capacity in organic solvents than unmodified Clay.

This research therefore demonstrates this organoclay can be used as sorbents in pollution prevention, oil spill and environmental remediation such treatment of landfill leachate.

\section{Acknowledgment}

Authors sincerely appreciate Prof. I.P. Okoye of the Department of Pure and Industrial Chemistry, University of Port Harcourt for his qualitative assistance in the course of this work

\section{References}

[1.] Abha, S. and Singh C.S. (2012). Hydrocarbon Pollution: Effects on Living Organisms, Remediation of Contaminated Environments and Effects of Heavy Metals Cocontamination on Bioremediation. In: Introduction to Enhanced Oil on Recovery (EOR) Processes and Bioremediation of Oil Contaminated Sites, Romero-Zeron, L. (Ed.). InTech Publisher, China, ISBN: 978-953-51-0629-6, pp. 186-206.

[2.] Orji, F. A., Ibiene, A. A. and Okerentugba, P. O. (2013). Bioremediation of Petroleum Hydrocarbon Polluted Mangrove Swamps Using Nutrient Formula Produced from Water Hyacinth (icchornia crassipes). American Journal of Environmental Science, Vol. 9, pp. 348- 366. 
[3.] Mbhele, P.P. (2007). (Remediation of soil and water contaminated by heavy metals and hydrocarbons using silica encapsulation). University of Witwatersrand, Johannesburg.

[4.] Abioye, O. P. (2011). Biological Remediation of Hydrocarbon and Heavy Metals Contaminated Soil. Soil Contamination, Pascucci, S. (Ed.),InTech Publisher, China, pp. 127-142.

[5.] Wang, J. (2006). Deep geological disposal of high-level radioactive wastes in china. Chinese Journal of Rock Mechanics and Engineering Geology. 25: 4

[6.] Asad, M., Shantanu, K., Ahmeduzzaman, M. and Hassan M. (2013). Suitability of Bentonite Clay: An Analytical Approach. International Journal of Earth Science, Vol. 2(3), pp. 88-95.

[7.] Emam, E. A. (2013). Clays as catalysts in petroleum refining industry. ARPN Journal of Science and Technology, 3(4), 356-375.

[8.] Emam, E. A. (2013). Modified activated carbon and bentonite used to adsorb petroleum hydrocarbons emulsified in aqueous solution. Am. J Environ Prot., 2(6), 161-169.

[9.] Pereira, K. O, Hanna, R. A, Vianna, M. M, Pinto, C. A, Rodrigues, M. G. and Valenzuela-Diaz, F. R. (2005). Brazillian organoclays as nanostructures sorbents of petroleum-derived hydrocarbons. Material Research. 8: 77-80. [10].

[10.] Safaei, M, Aghahozorg, H. R, Shariat, H. and Panahi, S. (2008). Modification of domestic clays for preparation of polymer nanocomposites. Nashrieh Shimiva Mohandesi Shimi Iran (NSMSI), 27.

[11.] ASTM, F726-99 (1998). Standard Test Method for Sorbent Performance of Adsorbents, in: Annual Book of ASTM Standards.

[12.] ASTM - American Society for Testing and Materials. 1982. Standard Methods of Testing Sorbent Performance of Adsorbents. ASTM Designation F716 -82 (Reapproved 2001). 